Article

\title{
Resilience through the Financialisation of Risks? The Case of a Dairy System in Northwest Germany
}

\author{
Thies R. Popp ${ }^{1, *(1)}$ and Wiebke Nowack ${ }^{2}$ \\ 1 Agricultural and Food Policy Group, Thaer Institute for Agricultural and Horticultural Sciences, \\ Humboldt-Universität zu Berlin, 10099 Berlin, Germany \\ 2 International Agricultural Trade and Development Group, Thaer Institute for Agricultural and Horticultural \\ Sciences, Humboldt-Universität zu Berlin, 10099 Berlin, Germany; wiebke.nowack@hu-berlin.de \\ * Correspondence: thies.rasmus.popp@hu-berlin.de; Tel.: +49-30-2093-46323
}

Received: 13 July 2020; Accepted: 30 July 2020; Published: 3 August 2020

\begin{abstract}
State support for financial risk management schemes has been introduced in numerous agricultural policies to enhance farming system resilience in response to increased income fluctuations and partially reduced producer support levels in the agricultural sector. In order to better understand how financialisation of risks can contribute to an actual improvement of specific farming systems' resilience, this study investigates its effects with regards to dairy farming. Based on an in-depth case study of a dairy system in Northwest Germany, multilayered challenges faced by the farm system are identified, resilience strategies investigated and the role of financial risk management evaluated. In doing so, the resilience assessment framework developed by Meuwissen et al. (2019) is applied in order to analyse the systems' capacity to resist, adapt or transform in response to external challenges threatening the provision of system' functions. The results indicate a high relevance of insurances and savings with regards to the system's robustness against short-term shocks. However, to address the various long-term pressures, resilience-enhancing attributes that increase the system's capacity to adapt and transform would need to be strengthened. In particular, more cooperation and knowledge transfer beyond system boundaries could contribute to a holistic risk management allowing for improved farming system resilience.
\end{abstract}

Keywords: agricultural policy; policy instruments; risk management tools; risk transfer; farming system; challenges; private and public goods; wellbeing

\section{Introduction}

Multilayered challenges have increased the vulnerability of Europe's farming systems in the recent past. Although prices for agricultural outputs reached a high level during the food price crisis between 2008 and 2011, many farms have been suffering under even higher costs of inputs, such as fertilizer or animal feed [1]. Within the European Union (EU), in particular, environmental production standards and consumers' expectations regarding animal welfare have increased and further contributed to rising production costs and public pressure [2]. Changes of the regulatory framework as well as dynamic trade relations have constituted additional challenges and reduced farms' planning reliability. For the dairy sector, which will be further investigated in this contribution, specifically the phasing out of the milk quota in 2015 with a simultaneous export ban of agricultural products to Russia resulted in serious sales problems for dairy products [3]. Next to political events and vulnerability to shocks on the global market, extreme weather events play an increasingly important role due to climate change. Most recently in 2018, a drought caused crop losses in many countries of the EU [4]. In reaction to such events, various ad hoc state interventions took place and sparked a debate on the subsidisation of financial risk management tools in the agricultural context [5]. The European 
Commission's proposal for a Common Agricultural Policy (CAP) post-2020 considers the support for financial risk management tools as an obligatory policy instrument for member states to transfer risks from the strongly weather-dependent agricultural sector to financial markets.

Historically, agricultural producer support has been an integral part of public policy in most high-income countries. While trade distortive policy instruments, such as tariffs and price interventions, dominated agricultural policy-making until the early 1990s, especially the results of the WTO Uruguay Round led to the intensive use of less or non-trade distorting direct payments as main policy instruments to support incomes of agricultural producers [6]. However, societal and environmental concerns and budgetary constraints combined with an increased visibility of wealth transfer from taxpayers towards the agricultural sector increased the need to legitimise these payments [1]. These developments have led to a continuing trend to liberalise agricultural markets, lowering overall state support levels, whereby a clear convergence of agricultural policies is missing [7]. There are huge differences among countries and regions though: while topographically disadvantaged countries, such as Switzerland or Norway, strengthened the link between payments and environmental services, competitive countries, such as Canada or the United States, shifted large parts of the remaining agricultural budget into a financial risk management scheme to protect farm income against yield and price-related uncertainties. In the EU, the CAP is under tremendous pressure. On the one hand, the decreased farm income stabilising effect by a melting CAP budget in combination with increased costs and fluctuating commodity markets cause farmers' displeasure. On the other hand, several studies and civil society organisations criticise the low impact of taxpayers' money on public services $[2,8]$.

In order to analyse potentials and limitations of state-supported financial risk management tools for a specific region and production system, we conducted a case study of a typical dairy system in Northwest Germany asking the following research questions: What are the challenges that dairy systems in Northwest Germany face? Which of the resulting risks can be transferred to financial markets to increase resilience?

The findings of this research suggest the promotion of resilience-enhancing attributes, which enable adaptability or even transformability of farming systems and contribute to an improved policy design of risk management considering regional and production-related differences.

First, implementation barriers and the potential of the insurance markets for farming systems are elaborated on based on a literature review. Furthermore, we explain the relevance of resilience-enhancing and non-enhancing policy instruments regarding the capacity to resist, to adapt or to transform as a response to external challenges. In Section 3, our methodological approach and the applied resilience framework are presented. Section 4 provides a systematic summary of our case study's results, which are further discussed in Section 5. Furthermore, the section evaluates the resilience-enhancing effect of state support for financial risk management tools. The paper concludes with a policy recommendation to improve the capacity to adapt or transform in response to the diverse and complex challenges of farming systems.

\section{Conceptual Framework}

\subsection{Insurance Markets and Agricultural State Support}

Traditionally, the main function of private insurances is to share independent production risks. In the past, however, they also have performed a social insurance function to a certain extent by covering several correlated natural catastrophe risks through the global diversification of risks. However, an increased frequency of weather extremes due to climate change and the concentration of large shares of insurance premiums in exposed areas caused huge losses and partly resulted in the reluctance of reinsurance companies dealing with natural disasters [9]. The literature on insurance markets identifies two different main paths to solve the related insurability problem: first, by public insurances that are subsidised with taxpayers' money and/or require compulsory memberships [10]; second, by transferring risks to financial markets [11]. 
On the one hand, the often cited problems of moral hazard and adverse selection describing the asymmetric information between the principal (e.g., insurance agency) and the agent (e.g., farmer), as well as the systemic character of several agricultural risks, such as drought or flooding in vulnerable areas, pose a high insolvency risk for local operating insurance agencies. Furthermore, non-traditional activities such as financial derivatives and guarantees have the potential to increase systemic risks of the insurance industry $[12,13]$. On the other hand, the policyholder's attitude and obstacles, such as limited resources, bureaucracy or problems regarding damage payments, are factors that reduce the demand for agricultural insurances [14]. These issues might prevent an extensive supply of financial risk management tools leading to some agricultural risks not being covered by market-based solutions $[15,16]$.

In most high-income countries, the state is withdrawing from agricultural policy resulting in an ongoing liberalisation of the agricultural sector [17,18]. In the EU, the slow but steady melting-off of the income supporting (direct) payments increases the market dependency of farmers. Simultaneously, this causes a higher need for risk management since a larger proportion of farm income is subject to production and market-related uncertainties [19]. There are diverse options for farms to engage in risk management. In addition to financial insurances against specific risks, farms, for instance, may pro-actively reduce their exposure to certain risks by adjusting their production system or diversifying their income sources [20]. In this study, the focus lies on the financialisation of risks and thus on (state-supported) insurance schemes. In this regard, the European Commission plans mandatory state support for financial risk management tools such as insurances, mutual funds or income stabilisation tools [21]. On a voluntary basis, member states have this option already since the CAP's reform in 2013 (Regulation (EU) No 1305/2013 article 36-39 allows financial contributions to insurance premiums; mutual funds for adverse climatic events, animal and plant diseases, pest infestations and environmental incidents or income stabilisation tools that compensate for drop of income above a set reference value.). Yet, not all member states make use of the available co-financed insurance options. In consequence, the state of insurance systems is quite different in EU member states [22]. In Germany, for example, mentioned risk management tools have not been subsidised so far and the crowding out of private insurances, such as the popular hail insurance, is feared by economists [23]. In Poland, the government prefers a nationally designed and funded insurance scheme and in Italy, Spain (Castilla y León) and Hungary, the intended set-up of CAP-supported income stabilising tools through mutual funds have not been implemented so far [24,25].

\subsection{Resilience}

While being originally developed in ecology [26], the concept of "resilience" is constantly evolving and increasingly applied to socio-ecological systems (SESs). One field of such applications concerns farming systems as regionally embedded actor networks, which are exposed to environmental, economic, social and institutional challenges that are strongly context dependent [27]. So far, in academia as well as political discourses related to agriculture, the focus often lies on economic and environmental challenges while social and institutional challenges are quite under-researched $[20,28]$. Using the resilience concept as a starting point allows one to take a holistic perspective and understand the impact of (potential) perturbations or stresses on the overall system and its capacity to deal with them over time [29]. Especially in the context of farming systems, the resilience concept offers an insightful perspective since they are embedded in local environments. In this contribution, we build up our conceptual perspective on the framework provided by Meuwissen et al. (2019) [30], who define a farming system's resilience "as the ability to ensure the provision of the system functions in the face of increasingly complex and accumulating [ ... ] shocks and stresses, through the capacity of robustness, adaptability and transformability". In general, farming systems fulfil several functions resulting from the provision of private and public goods. However, the production of these goods is subject to uncertainties and the degree of the related functions' provision can change over time. 
The three capacities, which play a key role in our analysis, originate in literature on adaptive cycles and thus in ecological systems thinking and have been previously distinguished in the context of socio-ecological systems, for instance by Walker et al. (2004) [26] or Gallopín (2006) [27]. In contrast to definitions of resilience, which emphasis a system's ability to maintain a present equilibrium [31], the applied definition integrates a more dynamic perspective and thus allows for changes within a system in reaction to external and internal shocks and stresses [30]. First, "robustness" describes the capacity to resist external shocks without significant changes. A robust system is able to maintain the level of output and the essential functions despite the occurrence of external perturbations. Second, "adaptability" describes the capacity to adjust internal operations facing external changes. An adaptive system is able to develop along its chosen development trajectory and continues to provide its key functions. Third, "transformability" describes the capacity to change the essence of the system in response to major changes in the system environment. A transformative system is able to change its structures when these have turned out to be unsustainable in order to fulfil demanded functions in the future. In the following, this research analyses which challenges of a dairy system are covered by financial risk management tools and to what degree these may enhance the capacity to resist, adapt or transform in times of crisis.

\section{Methodology}

The previously introduced framework to assess the resilience of farming systems allows us to examine agricultural challenges on a farm system level instead of on a farm level. Therefore, shocks and pressures arising along the value chain can be identified. This approach deviates from most other studies on agricultural risk management [20] and integrates environmental, economic, social and institutional constraints that are shaped by its characteristics and context. In order to identify Northwest Germany's dairy systems' resilience to current challenges and examine the need of state-supported financial risk management, we started with the presented resilience framework [30] as our conceptual basis and analysed the dairy sector with a qualitative case study approach. The applied framework suggests a system perspective that considers multiple stakeholders and interdependencies. Accordingly, in-depth interviews with all relevant actors of a representative dairy system in Northwest Germany were conducted and analysed in combination with available scientific publications and statistical data. In the following, the case selection and the case's geographical location as well as the setting of system limits will be presented and explained.

\subsection{Case Selection and Introduction to Its Geographical Location}

This case study is an in-depth analysis of one conventional dairy system in Northwest Germany. The analysed dairy system consists of a core that produces the main product(s) and its context that shape the production conditions [30]. In order to identify these, we started with an own preliminary stakeholder analysis combined with snowball sampling starting at the dairy farm in order to investigate the systemic environment and its challenges. Gradually we identified important actors for the dairy production using the information from the interviews and assigned them to the core or the context of the dairy system (for the result see Section 4.1). The farm at the centre of the selected case system is one of 12,500 dairy farms in Northwest Germany. Most of these are part of highly similar actor networks as the one analysed as part of the case system and, for instance, organised in cooperative dairies. A notable characteristic of the selected case's farm is its relatively large herd, which is almost five times larger than the average in Northwest Germany [32]. At the same time, growth has been the dominating and future-oriented trend in the sector, which is why the analysed farm and its environment is understood as constituting a representative case for most dairy systems in the region. Its analysis was expected to deliver detailed knowledge regarding relationships within such systems, which had not yet been well understood and are difficult to quantify [33].

Since there are almost no larger cities and agriculture employs almost six percent of the workforce (an important economic factor in the farm's district) [34], the focussed dairy system's environment is 
located in a relatively remote area, which has implications for its representativeness [35]. With reference to other dairy systems in Northwest Germany, especially those not located in the direct vicinity of a large city, the selected case is considered as paradigmatic. Next to very fertile marshland mainly cultivated by crop and vegetable farms at the coast, the region, in which the selected case is located, has a relatively high proportion of geest (higher landscape) and moorland towards the midland. The latter is mainly cultivated as grassland by livestock farms. Usually, these farms are organised as family farms [34]. Due to the temperate climate conditions and the rather small structures of the agricultural area, the region is seen as a favourable location for the German dairy industry, which is generally characterised by relatively high productivity as well as high export rates (around 50 percent) - predominantly in the form of cheese, butter and whole or skimmed milk powder [3]. Despite a high level of production and significant shares of agricultural producer support from the $\mathrm{CAP}$, on average, the factor wages of dairy farms are significantly lower than factor wages in other sectors and below the level of arable farms, as well [36].

\subsection{Interview Design and Data Analysis}

In total, 21 semi-structured interviews with 24 individuals served as a data basis for our analysis (see Appendix A). The interviews consisted of three main parts aiming to collect sufficient data for a thorough resilience assessment [30] considering the potentials and barriers of financial risk management tools [25,37]. The first section aimed to identify relevant stakeholders of the dairy system and potential interview partners and addressed experiences in the area of risk management as well as the business development. The second part aimed to identify challenges as well as respectively practiced mitigation or coping strategies. This was supposed to form the basis for the later assessment of the dairy system's resilience. The interview concluded with a third part of a personal assessment of different financial risk management tools including opportunities and limitations of these instruments (see Appendix B).

After transcribing audiotapes of the interviews, the data were coded with the help of the software MAXQDA 2018. For the coding, a deductive strategy was chosen and categories applied, which were developed from the earlier introduced resilience perspective [30]. In the first round of coding, we focused on the constellation of the dairy system, different short- and long-term challenges to provide system functions as well as mitigation and coping strategies. In the second round, we established the link between mitigation and coping strategies and the three types of resilience capacities (robustness, adaptability and transformation). In the third stage of our analysis, we coded inductively for the potentials and barriers of financial risk management tools and determined resilience-enhancing attributes. Both authors were involved in the interviews, the coding and the creation of memos ensuring a joint development of understanding and reflexivity along the entire research process.

\subsection{Potential Limitations}

This study focused on the challenges of dairy systems in Northwest Germany and the effects of financial risk management tools to enhance their resilience capacities. To provide an example, we analysed one dairy system that is typical for dairy systems in the region with reference to previously conducted desk research and personal contacts, as well as experiences from another case study project in the region. However, the dairy system is one of many diverse farming systems in Northwest Germany which is a specific region, even within Germany. Thus, findings cannot be transferred one-to-one to other regions or farming systems. Since one of the authors has personal relationships with individual actors, the response rate $(95 \%)$ was very high and the data were expected to be extremely reliable due to the minimised doorknob syndrome [38]. Yet, despite regular discussions within the research team, it cannot be ruled out that some facts in the data were not adequately explained and cause information gaps as some interviewees could have assumed that the interviewer knew the connections. Results were checked for plausibility and compared with other sources. In the following, 
the analysed farming system is based on the qualitative data that were gathered by the interviews. Depending on the focus of the research, the context of the system could be expanded or thinned out.

\section{Results}

\subsection{The Dairy System}

Overall, we could identify 21 actors who form the dairy system focused on, which all have a direct or indirect influence on the value chain (see Figure 1). Some of the actors interviewed held several roles, which even increases our analysis' coverage of perspectives. The core and, thus, the key actors of the analysed dairy system are the farm, the breeder, the adviser and the dairy. The farm is organised as a family farm with six employees; milks nearly 500 cows, 2.5 times a day and focuses on a cost-effective maximisation of the production. The cattle breeder is a phasing out dairy farm and long-term cooperation partner of the farm. The production pattern can be described as the following: the cattle breeder separates the few-weeks-old calves, feeds and later inseminates them. After two years, the heifers are returned to the dairy farm. Regularly, the same adviser unit, specialised on dairy production, consults the farm and the cattle breeder. Just like several hundred farms in the region, the analysed farm delivers the milk to the cooperative dairy, which specialises in the export of mass products. The members of the cooperative receive the payment and the announcement of the raw milk price in the following month.

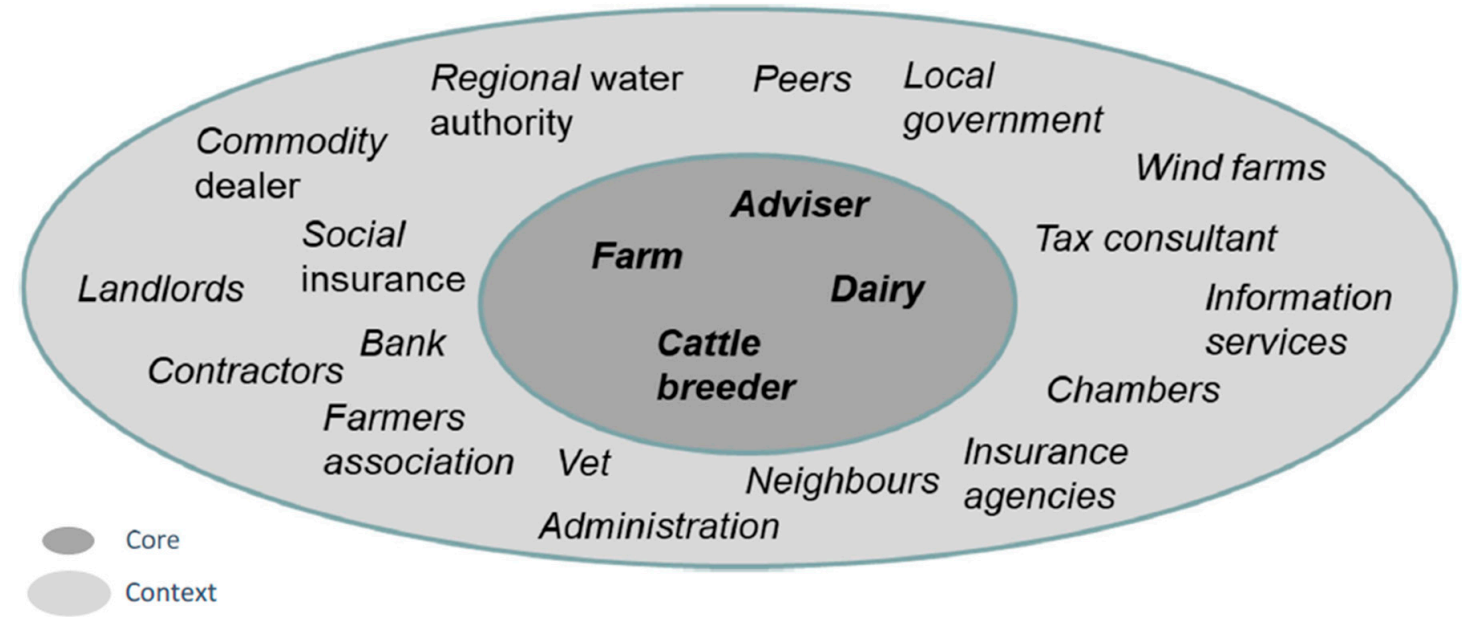

Figure 1. The dairy system.

The dairy system's context, which shapes the production conditions, consists of many different actors influencing the core directly or indirectly. The production of milk requires an adequate factor endowment of land, capital and labour. Therefore, several landowners, the local bank and contractors who support permanent employees in peak times are significant reserves for the core of the system. The farm and the cattle breeder purchase equipment and additional feed from the commodity trader who also buys the grain harvest. Different liability risks and losses are insured by a few local insurance agencies. Family members of the farm and the cattle breeder are insured by the national social security system of the agricultural sector (The Social Insurance for Agriculture, Forestry and Horticulture (SVLFG) is a federal body directly governed by public law. It is the holder of mandatory agricultural social insurances for farmers and their families covering occupational accidents, health, long-term care and old age.). The state administration of the land disburses subsidies of the CAP and operates a mandatory fund to fight animal diseases. In addition, different private and partially subsidised information services provide news, price information and, to some degree, financial education, for the agricultural sector. The core actors of the farming system are members of the agricultural chambers and the farmers' association and also use their advisory services specialised on agriculture in addition 
to the tax consultant. Furthermore, they connect to peers to receive information, administrative assistance or political representation. Although the farm, which the analysed dairy system is built around, is located outside of the village, potential reactions of neighbours or village inhabitants are considered in the daily work. Thus, these are also considered as context actors. The honorary work of the regional water authority and close ties to the local government are found to be very important to those involved due to a historically established joint feeling of responsibility and the high relevance of well-functioning water management with regards to the arable land. A special feature of the analysed region in Northwest Germany is the omnipresence of wind farms, which provide high additional income to their owners as well as the owners of the land the power plants are built on. Both are often farmers. These, we found, often use the respective revenues to invest in their farms, which provides them a comparative advantage - especially in terms of leasing or purchasing land.

Based on the interviewees' perceptions and the earlier introduced categorisation of system functions, whose provision is supposed to be ensured in a resilient system [30], the following private and public goods are provided by the dairy system: (1) the delivery of food products (dairy and meat products), (2) the production of renewable energy, (3) the generation of private income to the farmer, (4) the provision of employment to the region's inhabitants, (5) environmental care and landscaping, (6) community work and sharing of resources as well as (7) preservation of traditional values and (8) education of children with regards to agriculture.

\subsection{Challenges}

Farming systems face different potential short-term shocks and long-term stresses that can challenge their resilience, imply certain risks and threaten the provision of system functions. These challenges can be differentiated in environmental, economic, social or institutional dimensions. As shown in Table 1, this case study of a dairy system uncovered that only a minority of the numerous present challenges are of a short-term nature. The vast majority of challenges to the analysed system are long-term stresses. The diverse challenges were derived from the interviews and are sorted from top to down according to their perceived level of relevance. In the following, the different challenges summarised in the table are explained in more detail and underpinned by exemplary quotes from the interviewees.

Table 1. Challenges of the dairy system.

\begin{tabular}{|c|c|c|c|c|}
\hline & Environmental & Economic & Social & Institutional \\
\hline $\begin{array}{c}\text { Short-term } \\
\text { shocks }\end{array}$ & $\begin{array}{l}\text { - Extreme weather } *, * * \\
\text { - Animal diseases }{ }^{* * * *} \\
\text { - Pandemics } \\
\text { - Weeds and pests }\end{array}$ & $\begin{array}{l}\text { - Price volatility }{ }^{* *} \\
\text { - Non-payment } \\
\text { - Product reliability }\end{array}$ & $\begin{array}{l}\text { - Health * } \\
\text { - Family issues * }\end{array}$ & - Political decisions \\
\hline $\begin{array}{l}\text { Long-term } \\
\text { stresses }\end{array}$ & $\begin{array}{l}\text { - Nutrient management } \\
\text { - Water management } \\
\text { - Land scarcity } \\
\text { - Animal welfare } \\
\text { - Climate change } \\
\text { - Destruction of habitats } \\
\text { - Greenhouse } \\
\text { gas emissions }\end{array}$ & $\begin{array}{l}\text { - Low milk price level } \\
\text { - Increasing costs } \\
\text { - Capital intensity } \\
\text { - Labour supply } \\
\text { - Fake news } \\
\text { - New competitors } \\
\text { - Limited tradability } \\
\text { of milk } \\
\text { - Limited quantity control } \\
\text { - Short-term preferences } \\
\text { - Changing supply chains } \\
\text { - Milk alternatives }\end{array}$ & $\begin{array}{l}\text { - Structural change } \\
\text { - Reputation } \\
\text { - Succession } \\
\text { - Divergence of society } \\
\text { - Farming exit } \\
\text { - High workload } \\
\text { - Social } \\
\text { security system }\end{array}$ & $\begin{array}{l}\text { - Regulatory law } \\
\text { - Bureaucracy } \\
\text { - Uncertainty } \\
\text { - Complexity } \\
\text { - Closed networks } \\
\text { - Market liberalisation } \\
\text { - Delivery relationships }\end{array}$ \\
\hline
\end{tabular}

* Challenges that are (partially) insured or hedged by the dairy system. ${ }^{* *}$ Challenges that could be (partially) insured or hedged by the dairy system.

Starting in the upper left of the table, one of the interviewees put in a nutshell what was highlighted by many and said, "Agriculture is an outdoor workbench". Accordingly, environmental shocks in the form of weather extremes—such as storm, drought or moisture-would occur frequently and cause 
crop yield losses potentially resulting in fodder shortages or shorter tillage periods. Animals' diseases were found to be a serious threat to the system's resilience too, constituting a high permanently existing risk and a serious short-term shock once a disease breaks out. In the past, the mad cow disease and the BHV1 virus caused several cullings in Northwest Germany. Most recently, the COVID-19 pandemic, also categorised as a short-term shock on the environmental side, caused different effects across dimensions. For instance, it caused faltering value chains and changing consumer behaviour that decreased raw milk prices. Apart from that, a frequent danger to the crop harvest are pests, but also ordinary weeds such as the poisonous Jacob's herb were mentioned to challenge the dairy system.

In the long-term, nutrition and water management were pointed at as the most relevant continuous environmental stresses. A rising sea level and increasing weather extremes due to climate change are expected to make it more difficult to drain off and protect against water as an expert of the regional water authority elaborates, "The sea level and the silting up in front of the riverbed increase. At the same time, the moors decrease due to the drainage. This process of mineralisation and also the release of greenhouse gases will complicate water management in the future." Yet, the awareness of climate-change-related dynamics regarding environmental challenges was found to be not as high when it came to the key actors of our system. Furthermore, the concentration of animal populations and regional exceeded limits of nitrate influences were reported to complicate the distribution of manure on the scarce agricultural land. At the same time, several interviewees emphasised an increasing competition for land due to sealing, renewable energy production or nature conservation. In addition to land price distorting effects of regenerative energies that were identified for the case study's region, in particular, state support for nature conservation foundations leads to a growing demand for land for nature conservation. Consequently, farmers can no longer use the land intensively and are missing the income-supporting direct payments for the agricultural land. Many try to compensate by increasing their productivity resulting in more manure and less agriculturally integrated nature conservation through the area competition. While increasing animal welfare is seen as an important challenge with associated positive effects on the milk production, the effects of the destruction of habitats and long-term impacts of greenhouse gas emissions on climate change are at least questioned. This is how an interviewee puts it: "So, my grandpa said there have always been good and bad years. We should not interpret too much in it now.".

Especially in the last two decades, economic shocks were emphasised to play an important role for the dairy system. In particular, the high price volatility on global dairy markets was mentioned to be a major challenge for the export-oriented production, but also varying input prices-for example, in the case of fodder or fertilizer. The latter caused serious liquidity problems within the system and resulted in an increased non-payment risk. Another issue mentioned concerns audits along the value chain, which are supposed to guarantee high food safety for consumers. Apart from their value regarding consumer protection, the audits pose a certain reliability risk for the dairy system in case of poor production results as the example of the cattle breeder and former dairy farmer describes, "I always tried to produce really good milk and if I had a bad production, I opened the tank again. That is how it was. I didn't deliver any crap.".

In the long-term, the low milk price level is by far seen as the most serious problem on the economic side. Combined with increasing costs caused by relatively high standards, lack of labour force and new competitors on the land market, a cost-price squeeze has developed and margins have decreased dramatically. Frequently, farmers' coping strategy seems to have consisted of compensating the low margin by an increased production with a higher leverage, which have been supported by low interest rates. This exacerbates the overproduction on the price-sensitive global dairy markets where the EU is one of the price-setting players as the manager of the dairy explains, "We have the effect that the farmers start milking more as a counter-reaction due to the rising costs. This is of course completely counterproductive. We have too much milk in the market anyway. However, of course every farmer looks at its own cash and says that he has to get even more out of the cows." Other aspects, which were brought up concerned the perishability of fresh milk and the resulting limited tradability 
as well as the limited quantity control of production. Furthermore, the capital intensity of modern production techniques requires a high level of leverage and long-term investments. These again underlie uncertainties, such as changing supply chains, fake news that obscure farming issues or shifting consumer preferences towards milk alternatives.

Although social challenges of farming systems are rarely discussed in academia, they are an important element in strategic business decisions as it became clear in our interviews. In fact, the dairy system implies a relatively high risk of short-term shocks on the social level, first and foremost with regards to the deterioration of the farming family members' human health. In particular, work accidents with cattle, developed allergies or zoonoses were mentioned as examples. In the extreme case, such incidences are reasons for an early inability to work. For a family-run dairy farm, also divorce, generational dispute or death cause psychological burden and can endanger the existence of the whole farm.

In the long-term, the structural change within the agricultural sector is seen as a major pressure. "At the moment, the mood on the farms is really bad", said an adviser. With reference to the previous decade, a damaged reputation of the sector, a lack of passionate successors and an increasing divergence of society and dairy production were mentioned as additional reasons for ongoing phasing out processes in numerous farms in the region. Yet, in most cases, these were planned and well prepared. For a takeover by the successor, the high workload within the system and especially the successor's payment obligations towards the old generation(s) are conceived as relevant barriers. In the case study's region, a retired farmer usually receives only a small public pension in addition to payments of the successor or off-farm income. Often, this additional income would increase the remaining social insurance contributions of potential pensioners, making it cheaper to continue farming. Despite the fact that the social security system of agriculture and forestry in Germany is already heavily subsidised by tax money and farmers contributed over decades, many do not call the pension.

At the latest since the milk quota expired in 2015, also the dairy sector became aware of the importance of the institutional framework. Although most political decisions take time until they are legally implemented, they can also hit the system as a short-term shock in certain situations. For example, the expiring of the milk quota in combination with the Russian trade embargo as a consequence of the Crimea crisis resulted in deep losses that were not anticipated to that extent.

In the long-term, the relatively high process and production standards in Germany, especially in the area of environmental protection and construction, are perceived as a serious threat to the global competitiveness of the region's agricultural sector independently from specific farming systems. Apart from this, the high level of bureaucracy, the increasing complexity of the work area and general uncertainty in institutional decisions, such as approval procedures, were reported to cause frustration and additional information costs. It was noticeable that the dairy system interacts in rather closed networks, so that new actors, problems or ideas coming from outside of these networks take a while to be recognised. Recent scientific results seem to be often unknown or ignored and the new laws of the liberalised milk market have largely not yet been internalised as the bank expert elaborates, "We know the rhythms in pig cycles, but we simply do not know them in dairy farming. Of course, we had this price valley from 15/16. Then we had a very wet year 17. A dry year in 18/19. What is normality there?" This lack of planning security is also evident in the supplier relationship between the farmer and the cooperative dairy. Despite cooperative shares and voting rights, the active participation culture of farmers is low. While the farms see price hedging at the dairy, the dairy sees the responsibility among the farmers.

\subsection{Resilience Measures}

We found several different measures that the dairy system in Northwest Germany developed to cope or mitigate the identified challenges securing its wellbeing and the provision of the systems' functions. Many of these were introduced intentionally, some were passed on from generation to generation and few were done for other purposes with unintended positive effects concerning the 
system's capacity to encounter challenges. Table 2 categorises these resilience measures, which we identified based on the interviews, by their capacity to improve the robustness, adaptability or transformability of the system. The more relevant actors perceived a measure for the system's resilience, the higher it appears on the list.

Table 2. Measures applied by the analysed dairy system categorised according to resilience capacities.

\begin{tabular}{lll}
\hline Robustness Measures & \multicolumn{1}{c}{ Adaptation Measures } & Transformation Measures \\
\hline - Insurances and savings & - Product innovation and niches *** & \\
- Specialisation & - Technology & - Renewables \\
- Growth & - Cooperation & - Nature protection $* * *$ \\
- Price hedging *** & - Trainings & - Tourism \\
- Employees & - Cultivation adjustments & - Working off-farm \\
- Breeding & - Resource efficiency & - Pension \\
- (Inter-)dependencies & - Second location $* * *$ & - Farm shop ** \\
- Quality standards & - Biosecurity measures & - Care and education \\
- Storage & & \\
\hline
\end{tabular}

The analysis shows a broad variety of resilience measures to resist external challenges without significant changes within the dairy system, which indicates a solid robustness. In short, such measures contribute to provide buffer resources and compensation mechanisms for unforeseen losses. Insurances and savings seem to be the most important measures when it comes to the business' protection against weather extremes, animal diseases, liability risks, non-payment, health problems or other unforeseen shocks. Still, there are important differences according to the regional manager of an agricultural insurance agency, "For 15 years we have also been offering storm, heavy rain and frost insurances, but here farms have remained very hesitant. However, that dairy farms insure maize against storm damages is done more often. The other dangers of frost or heavy rain: the farmers do not see that this is really occurring." Growth in herd size, specialisation and science-based breeding techniques for cattle are practiced to increase productivity and generate cost advantages compared to competitors. Price hedging on commodity futures exchanges is seen as a relevant option to counter price volatility. However, it was found that neither the dairy farm nor the dairy or involved financial institutions have the capacity to deal with it seriously. In order to increase the efficiency of the system, the dairy system continuously optimises its processes and production factors at expense of the capacity to adapt or transform, as the manager of the dairy constitutes, "Of course we try to optimise the added value. This is a fine thing. We can do that as a dairy and since the change of our strategy several years ago, we have always been above the average of the payments. That is good, it helps us, but it does not solve the problem. The problem affects the entire dairy industry. That means the solution is somewhere else." Further measures include hiring of employees and provision of storages that enable more flexibility. (Inter-)dependencies with neighbours or peers as well as the use of quality standards aim to address societal concerns.

Several of the resilience measures adjust internal operations in response to external changes, but they are not very pronounced in the dairy system as the interviews revealed. Product innovation and niches, such as the shift to organic farming, are mentioned to be frequent considerations in dairy systems in general, but have not been pursued by the farm analysed as part of the selected dairy system due to multidimensional changes and high uncertainties. A great hope of reducing costs and solving environmental problems of almost all actors lies in the use of new technologies such as precision farming or robotic techniques.

Normally, it was explained, training courses are attended by the leaders of an enterprise or organisation that is part of the dairy system and who passes on the knowledge to other employees and members. In the past, an exemplar innovation that was implemented by the farm in consequence 
of such a training concerned cultivation adjustments, such as undersowing grass in maize, in order to fulfil greening requirements of the CAP, to reduce weeds and to avoid soil erosion. As the strong presence of cooperatives in the agribusiness shows, cooperation is a common means in the farming sector and sharing specific machines or work force has a long tradition. However, in our case study, we found that in the context of nutrient management, potential benefits from cooperation between dairy and arable farms are not fully exploited.

"Agricultural land is limited. Usually, someone has to get out of the sector so that land becomes free. Otherwise, the dairy farm has to reduce the livestock or enter into a cooperation with an arable farm to comply with the revised fertilizer ordinance. The manure belongs to the crops, in order to create a closed circulatory system, as it is intended in the organic sector, for example. That should be focused even more by the livestock farms. However, farmers find it a bit difficult to talk to each other."

-An expert from the agricultural chambers

Many interviewees highlighted that growth and investments in new buildings as part of their existing farm site involve a lot of bureaucracy and long-lasting citizen participation. In order to avoid these obstacles, the opening of a second location or subsidiaries is seen as an option in the future. The experienced animal diseases in the past and the current COVID-19 pandemic caused an increased awareness of the need for biosecurity measures, such as rodent control or regular disinfection.

Finally, a few remarks are to be made on resilience measures that improve the dairy system's capacity to transform the operational logic and create alternative exit options for the actors involved. According to our conceptual understanding and the collected data, income diversification strategies are most important here. In the whole region and independently from the specific farming system, the most relevant diversification strategy is the investment in renewables such as solar or wind energy. However, in the competition for the coveted locations near the coast for wind turbines, arable farms are generally the leaders due to their location and larger area.

"The observation is actually that the farms which seem financially solid and are a bit bigger than others, indeed have renewable energies. Mainly wind. They reinvest what they take in and then do tourism. [... ]. The small dairy farms in the geest area have traditionally always had a hard time."

-Local politician

Apart from that, nature conservation turned out to gain importance as a potential source of income and strategic alignment. Although an activity as a nature conservationist does not go hand in hand with the dairy system's self-image as a food producer and raises concerns about the long-term use of agricultural land, many actors of the dairy system consider focusing more on landscape conservation in the future. In particular, the persistent subsidence of the soil and the rising water level in the moor areas lead to an increased pressure to act.

"We are trying to build up structures to give farms that want to continue intensive dairy farming the opportunity to do so. However, we also want to give those opportunities, who want to work as landscape conservationists, for example. We think there will be alternative forms of management. Of course, they must be rewarded."

-District manager of the local water authority

The geographical location of the analysed dairy system generally offers the possibility to engage in tourism by offering farm holidays, a farm café or holiday apartments. Such diversification options were found to be chosen by the cattle breeder in the analysed system as part of his phasing out strategy. Several advisers of the dairy system recommended these diversifications strategies successfully to numerous farms in the region. Other income diversification options at the farm level such as farm 
shops, educational offers or care work turned out to be less relevant due to their specific requirements on a farm's location, resources and family members' interest and play a minor role in the specific case we looked at. Additionally, it was mentioned that pensions and working off-farm are typical additional income sources of a multi-generation family-run farm such as the dairy farm at the core of our farming system. These income sources reduce the risk from agricultural income and offer transformation trajectories and a gentle exit for individual farms while the regional milk production remains and is taken over by other farms.

\subsection{Financial Risk Management Tools}

In the examined dairy system, the actors consider insurances and savings as the most important tools to ensure the system's resilience and wellbeing. With regards to most of the identified short-term shocks, the risks of their occurrences could be insured or hedged through public or private risk management tools (see Table 1). However, in practice, several significant risks are not managed as the two following challenges exemplify. First, only a few weather-related risks such as hail were found to be insured in the dairy system, although other insurances would be available on the market. High premiums due to limited reinsurance options for systemic risks and the complexity of the products could be identified to prevent a wide acceptance of financial instruments, such as indemnity or index-based insurances. The insurance expert also describes the trade-off between simplicity and precision caused by limited data availability as a major issue, "If the insurance does not exactly match the actual yield, it usually becomes complicated, which in turn is difficult to explain to the farmer, because he often says: this is too abstract for me now, I don't go with it." Second, as previously pointed out, the volatility of milk prices became a serious concern since the abolishment of the milk quota in 2015. Although the prices could be hedged on the commodity futures exchange, neither the dairy nor the dairy farm makes use of it. A major obstacle was found to be that only very few banks or financial service providers support the dairy system to hedge prices. After the financial crisis in 2007-2008, the EU financial regulations such as the Markets in Financial Instruments Directive (MiFID 2014/65/EU) were tightened to prevent misuse, excessive speculation and incorrect advice in financial derivatives. However, this has also caused more bureaucracy and effort for financial service providers when advising hedging of small and medium-sized companies. The financial expert of the information provider highlights, in particular, the bureaucracy and the complexity of financial risk management tools as barriers that increase costs,

"If the farmer has a position, every day he receives a letter from the clearing bank of how his position has changed. There is no way of looking online at the moment. He always has to call his broker and then the broker must be able to track what he has booked per customer [... ]. This process is insanely manual for the farmer. Not only when booking, but also when managing the portfolio."

-Financial expert of the information provider

Frequently, we found, banks avoid the effort and the liability risk of providing guarantees for the clearing bank, which increases liquidity costs for hedgers who have to deposit a margin. Furthermore, over-the-counter (OTC) trades (contracts are not traded on the commodity futures exchange) and limited broker competition result in illiquid commodity markets and high basic risks for dairy products.

The interviews as well as the analysed documents revealed the social insurance specialised on farm families and the mandatory animal disease fund of the state as typical examples for public insurances. These public risk management instruments share costs and losses between farmers with the help of funds that are partially funded by tax money. In the past, events like the milk price crisis in 2015 or the drought in 2018 caused the granting of governmental ad hoc payments for farmers, inter alia, in Northwest Germany. These payments were highly criticised by the actors of the dairy system. Many farmers did not meet the criteria and complained about the bureaucracy or the late payment due to the intensive examination through the administration. 
"The drought aids were just too bureaucratic and the one who really had a damage got nothing. That was superfluous and it could have been saved. There are companies that have benefited from it and received something. However, our dairy farms here in the region have not received anything. Although the loss was high, we could not prove it because it is not common for feed to be weighed before it is placed on the silo. That never happened, but this demand came after the silage had already been brought in."

-Expert from the farmers' association

Consequently, actors of the dairy system call for simpler instruments that provide prompt and exact compensation payments at fair premiums. As Figure 2 illustrates, these expectations of the analysed dairy system are difficult to meet by the financial sector. While the indemnity-based insurance causes usually high costs due to the individual damage assessment that increase the insurance premium, the functioning of the index-based insurance is still rather unknown and frequently, the lack of precise local data results in a complex basic risk between measured values and real losses. In particular, the high bureaucracy, limited data availability and little experience with financial instruments impair the marketability of risks and lead to an unnecessary vulnerability of the dairy system to several short-term shocks.

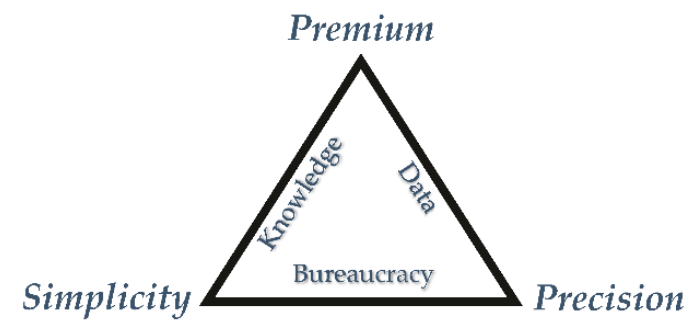

Figure 2. Triangle of insurance needs and barriers.

\section{Discussion}

This research investigated challenges of a dairy system in Northwest Germany, assessed the system's resilience and aimed to clarify whether state support for financial risk management tools is a needed policy instrument to improve the capacity to encounter short-term shocks and long-term pressures. Therefore, the focus of this research was put on financial risk management tools with regards to the system's capacities to deal with the identified challenges and implied risks while assuring the provision of its system functions. Although the findings are only deducted from one case, the character of the farming system is typical for the region and the above-average size of the farm reflects ongoing structural trends in the agricultural sector. These properties allow more generally valid conclusions for the region's dairy systems, including a look into the near future assuming that herd size growth will continue to be a main farm development strategy. Furthermore, an analysis focussing on the resilience-enhancing effects of policy instruments indicates comparable results for a dairy system in Flanders (Belgium) and identifies the CAP's policy measures as a major force that enables robustness and partially adaptability, but constrains transformability [39].

The findings of the in-depth case study of the dairy system show that a large number of short-term shocks can be insured or hedged. Even if the premiums lower the system's liquidity and appear rather high for systemic risks, there are some offers covering challenges such as drought or flood. However, many of the long-term stresses were found to be generally not transferable to financial markets. In particular, the insurance of long-term pressures seems vulnerable to moral hazard that could result in a lack of responses to threats like climate change. To overcome this issue, the insurance agencies would have to request adaptive actions to reduce the risk from the long-term stress. Although adaptive measures are cumbersome to monitor, the conditionalisation of simple insurance products that address long-term stresses at fair premiums might improve the overall resilience of dairy systems. In addition to the obligatory membership in the state animal disease fund that prevents the opportunistic behaviour of 
livestock owners and helps to fight pandemics, the analysis identifies several private examples, such as the hail or business liability insurances, which insure idiosyncratic risks very well through the market. Nevertheless, a suitable example for the proof of deficits in financial risk management is the price hedging on the commodity futures exchange. In line with Bezzina and Grima (2012) [40], who identify relevant factors affecting the proper use of derivatives, the dairy system is aware of the benefits and perceive price hedging as a useful tool. However, limited expertise and resources, high regulations and the misuse during the food price crises in the early 2000s prevent the engagement of actors involved. As the results show, the reasons for the poor acceptance of financial risk management tools are complex, so that a blanket premium-reducing subsidy of these instruments does not seem expedient to address regional and production-type differences. Rather, it needs a framework that provides publicly accessible data, improves financial education of farmers in this area and cuts bureaucracy for business' insurances and hedging instruments. Although the illustrated needs and barriers of insurances (see Figure 2) might look like a new concept to the reader, the call for an improved environment for risk transfers in agriculture have been raised by several authors that discuss, for instance, the high level of bureaucracy in Germany [23], the complex relationship between coverage levels and the willingness-to-pay [41] or the globally inconsistent handling of weather data [37]. Therefore, additional efforts, in particular by the state and financial institutions, seem to be required.

The analysis differentiates between three capacities enhancing the resilience of a farming system. Overall, the rather closed network of the dairy system in Northwest Germany shows a high robustness. This we conclude from the high number and the relevance of identified measures that aim to improve the robustness. Current political interventions such as the CAP's direct payments are found to support the system's robustness by stabilising the cash flow and increasing the system's creditworthiness. Furthermore, the low prime rate of the European Central Bank enables a continuous increase in the productivity of agricultural practices in temperate climate conditions. The dairy system's ability to adapt to occurring challenges is rather limited. Although collaboration and cohesion has a high priority within the core of the system, the interaction with and participation of diverse actors, such as environmental organisations or consumers, are underdeveloped. This is exemplified by the cooperative dairy, which grants raw milk prices above the low market average through process optimisation maintaining the status quo instead of developing product innovations meeting changed consumer preferences or hedging prices for its vulnerable members. The close ties and feedback loops within the system promote the exchange of existing knowledge like technology, but seem to slow the incorporation of new scientific knowledge into agricultural practices like measures to counteract climate change or biodiversity losses. Frequently, fake news diminishes trust in new information while the reproduction of decades-old beliefs and limited reflexivity of the relatively closed system lead to the fact that the opposing information is initially ignored. However, the analysed dairy system provides several examples of potential transformation paths for a future collapse. Especially state subsidies for renewables or nature conservation offer alternative income sources for landowners, but also a broad network and trust placed in the system facilitate transformation. For future farm successors, it might be problematic that these non-agricultural activities contribute to the system's income and competitiveness, but do not fall under the agricultural inheritance law. Therefore, in practice, the assets often remain with their predecessors or siblings.

The application of the resilience framework reveals several resilience-enhancing attributes of the analysed dairy system that seem to enhance the resilience by an improved capacity to resist, adapt or transform. Firstly, the use of innovations, information and science-based knowledge has proven to be beneficial for agricultural practices and increased the capacity to resist, adapt or transform in response to different challenges. Furthermore, system reserves such as a good equity ratio and land ownership facilitate access to cheap capital, which is urgently needed by many farms in the case study region. Secondly, a certain degree of flexibility and easily accessible policy programmes are essential features of resilience enhancing governance mechanisms. Thirdly, the managers' risk attitude and tight feedback loops are relevant factors for a resilience-enhancing risk management of the system. 
Fourthly, a broad and diverse network is a relevant feature of farm demographics and is found to be crucial with regards to the cross-generational takeover of the system. In particular, synergy effects through common interests and knowledge transfer through cooperation-e.g., among farms, dairy and consumers-seem to play an important role and still offer a lot of potential for dairy systems. Mutual funds, LEADER or EIP-Agri may be policy instruments of the CAP that could be strengthened and made use of in this context $[24,39]$.

\section{Conclusions}

This study identified challenges of a dairy system in Northwest Germany and analysed whether related risks can be transferred to financial markets to increase resilience. Applying the resilience assessment framework [30], the in-depth case study shows that the provision of private and public goods of the analysed farming system is threatened by a variety of short-term and long-term challenges.

State support for financial risk management tools might increase the uptake of existing insurance options due to reduced premiums and, thus, promote the robustness of dairy systems with regards to short-term shocks. Yet, our case study indicates that Northwest Germany's dairy farms' robustness is relatively high anyhow, while capacities to adapt or transform are limited. However, these two resilience capacities are essential to address the overwhelming long-term pressures of the farming sector.

Our findings suggest that resilience-enhancing attributes should be strengthened to provide framework conditions that facilitate a comprehensive risk management on a system level rather than funding individual policy instruments on a farm or area level. Therefore, the opening of rather closed farming systems seems crucial. A promotion of cooperative and trust-building measures beyond existing system boundaries might be beneficial for such a development [42]. In addition to this policy recommendation, the research adds novel contributions to the academic debate. First, the case study provides empirical evidence for the relatively young discussion on resilience in agriculture and helps to understand the interconnectivity of farming systems. Second, the application of the resilience assessment framework suggests a multidimensional perspective on the debate of risk management tools in agriculture, uncovers the high relevance of social and institutional risks in a farming system's everyday reality and raises additional concerns about state support for those instruments. In future, a focus on risk-minimising effects of cooperation and interaction beyond system boundaries might be rewarding for further research contributing to the sustainability and wellbeing of farming systems.

Author Contributions: T.R.P.: Conceptualisation, methodology, validation, formal analysis, investigation, resources, data curation, writing-original draft preparation, writing-review and editing, and visualisation. W.N.: Investigation and writing-review and editing. All authors have read and agreed to the published version of the manuscript.

Funding: This research received no external funding.

Acknowledgments: The authors thank Peter H. Feindt for his helpful comments. Furthermore, we acknowledge support by "Förderverein für Agrar- und Gartenbauwissenschaften an der Humboldt-Universität zu Berlin e.V." and the German Research Foundation (DFG) and the Open Access Publication Fund of Humboldt-Universität zu Berlin.

Conflicts of Interest: The authors declare no conflict of interest. 


\section{Appendix A}

Table A1. Data basis.

\begin{tabular}{|c|c|c|}
\hline No. & Role of Interviewee-Sideline & Key Points \\
\hline 1 & $\begin{array}{l}\text { Farm (married couple) } \\
\text { - Bank }\end{array}$ & $\begin{array}{ll}- & \text { Low milk price level } \\
\text { - } & \text { Increasing costs } \\
\text { - } & \text { Capital intensity }\end{array}$ \\
\hline 2 & $\begin{array}{l}\text { Cattle farm (married couple) } \\
\text { - Landlord } \\
\text { - Wind farm }\end{array}$ & $\begin{array}{ll}\text { - } & \text { Political decisions } \\
\text { - } & \text { Bureaucracy } \\
\text { - } & \text { Cooperation }\end{array}$ \\
\hline 3 & Dairy (manager) & $\begin{array}{ll}\text { - } & \text { Cost efficiency } \\
\text { - } & \text { Oversupply } \\
\text { - } & \text { Market power }\end{array}$ \\
\hline 4 & $\begin{array}{l}\text { Adviser (cattle specialist) } \\
\text { - Farm/Peer }\end{array}$ & $\begin{array}{ll}\text { - } & \text { Structural change } \\
\text { - } & \text { Regulation law } \\
\text { - } & \text { Divergence of society }\end{array}$ \\
\hline 5 & $\begin{array}{l}\text { Bank (agricultural specialist) } \\
\text { - Farm/Peer }\end{array}$ & $\begin{array}{ll}- & \text { Profitability } \\
\text { - } & \text { Liability } \\
\text { - } & \text { Renewables }\end{array}$ \\
\hline 6 & $\begin{array}{l}\text { Agricultural chambers (adviser) } \\
\text { - Farm/Peer }\end{array}$ & $\begin{array}{ll}\text { - } & \text { Extreme weather } \\
\text { - } & \text { High workload } \\
\text { - } & \text { Succession }\end{array}$ \\
\hline 7 & $\begin{array}{l}\text { Farmers' association (district manager) } \\
\text { - Peer }\end{array}$ & $\begin{array}{ll}\text { - } & \text { Low milk price level } \\
\text { - } & \text { Nutrient management } \\
\text { - } & \text { Reputation }\end{array}$ \\
\hline 8 & $\begin{array}{l}\text { Tax consultant (manager) } \\
\text { - Wind farm }\end{array}$ & $\begin{array}{ll}- & \text { Regulation law } \\
\text { - } & \text { Bureaucracy } \\
\text { - } & \text { Divergence of society }\end{array}$ \\
\hline 9 & Local government (member of parliament) & $\begin{array}{ll}\text { - } & \text { Land scarcity } \\
\text { - } & \text { Capital intensity } \\
\text { - } & \text { Weather extremes }\end{array}$ \\
\hline 10 & $\begin{array}{l}\text { Regional water authority (district manager) } \\
\text { - Landlord }\end{array}$ & $\begin{array}{ll}\text { - } & \text { Water management } \\
\text { - } & \text { Nutrient management } \\
\text { - } & \text { Climate change }\end{array}$ \\
\hline 11 & Insurance agency (regional manager) & $\begin{array}{ll}\text { - } & \text { Extreme weather } \\
\text { - } & \text { Complexity } \\
\text { - } & \text { Political decisions }\end{array}$ \\
\hline 12 & Social security system (head of department) & $\begin{array}{ll}\text { - } & \text { Structural change } \\
\text { - } & \text { Health } \\
\text { - } & \text { Family issues }\end{array}$ \\
\hline
\end{tabular}


Table A1. Cont.

\begin{tabular}{|c|c|c|}
\hline No. & Role of Interviewee-Sideline & Key Points \\
\hline 13 & Animal disease fund (head of department) & $\begin{array}{ll}\text { - } & \text { Animal diseases } \\
\text { - } & \text { Pandemic } \\
\text { - } & \text { Structural change }\end{array}$ \\
\hline 14 & District administration (head of division) & $\begin{array}{ll}\text { - } & \text { Cooperation } \\
\text { - } & \text { Renewables } \\
\text { - } & \text { Care and education }\end{array}$ \\
\hline 15 & Veterinarian & $\begin{array}{ll}\text { - } & \text { Regulation law } \\
\text { - } & \text { Bureaucracy } \\
\text { - } & \text { Animal welfare }\end{array}$ \\
\hline 16 & Commodity dealer (manager) & $\begin{array}{ll}\text { - } & \text { Increasing costs } \\
\text { - } & \text { Political decisions } \\
\text { - } & \text { Regulation law }\end{array}$ \\
\hline 17 & Contractor & $\begin{array}{ll}\text { - } & \text { Capital intensity } \\
\text { - } & \text { Cooperation } \\
\text { - } & \text { Labour supply }\end{array}$ \\
\hline 18 & Neighbour & $\begin{array}{ll}\text { - } & \text { Structural change } \\
\text { - } & \text { Political decisions } \\
\text { - } & \text { Reputation }\end{array}$ \\
\hline 19 & $\begin{array}{l}\text { Information service (manager and head } \\
\text { of finance) }\end{array}$ & $\begin{array}{ll}\text { - } & \text { Price volatility } \\
\text { - } & \text { Complexity } \\
\text { - } & \text { Bureaucracy }\end{array}$ \\
\hline 20 & $\begin{array}{l}\text { Landlord } \\
\text { - Peer }\end{array}$ & $\begin{array}{ll}\text { - } & \text { Water management } \\
\text { - } & \text { Increasing costs } \\
\text { Extreme weather }\end{array}$ \\
\hline 21 & $\begin{array}{l}\text { Wind farm (manager) } \\
\text { - Farm/Peer }\end{array}$ & $\begin{array}{ll}\text { - } & \text { Political decisions } \\
\text { - } & \text { Bureaucracy } \\
\text { - } & \text { Reputation }\end{array}$ \\
\hline
\end{tabular}

\section{Appendix B}

Table A2. Sample questionnaire for the farm ${ }^{* * * *}$.

\begin{tabular}{cc}
\hline & The Agricultural System \\
\hline $1 \mathrm{a}$ & Please describe the development of your farm. \\
$1 \mathrm{~b}$ & Which people or partners are important for the success of your farm? \\
$1 \mathrm{c}$ & How do you see the farm in 10 years? \\
$1 \mathrm{~d}$ & What functions does dairy farming in Northwest Germany provide from your perspective? \\
\hline \multicolumn{2}{c}{ Challenges of the Dairy System } \\
\hline $\mathrm{a}$ & What economic challenges does the farm face? \\
$2 \mathrm{c}$ & What environmental or animal-related challenges does the farm face? \\
$2 \mathrm{~d}$ & What social challenges does the farm face? \\
$2 \mathrm{f}$ & What political or institutional challenges does the farm face? \\
$2 \mathrm{~g}$ & How could these risks be hedged or mitigated? \\
\hline
\end{tabular}


Table A2. Cont.

\begin{tabular}{cc}
\hline & Agricultural Risk Management and the Role of the State \\
\hline 3a & To what extent is the implementation of new risk management tools necessary? \\
$3 \mathrm{~b}$ & To what extent should the state subsidise protection against the risks mentioned? \\
$3 \mathrm{c}$ & The current proposal of the EU Commission suggests that member states should subsidise risk management \\
$\mathrm{3d}$ & tools, such as insurance premiums, mutual funds or income stabilisation instruments. What do you think? \\
$\mathrm{3e}$ & What would be prerequisites for a high utilisation of risk management tools in the dairy sector? \\
\hline
\end{tabular}

\section{References}

1. Swinnen, J.F.M. An imperfect storm in the political economy of the common agricultural policy. In The Political Economy of the 2014-2020 Common Agricultural Policy: An Imperfect Storm; Swinnen, J.F.M., Anania, G., Eds.; Centre for European Policy Studies (CEPS), Rowman \& Littlefield International: Brüssel, Belgium; London, UK, 2015; pp. 443-484, ISBN 9781783484843.

2. Nowack, W.; Hoffmann, H. 'We are fed up'-Encountering the complex German call for sustainable, small-scale agriculture. J. Peasant Stud. 2019, 1-10. [CrossRef]

3. Hunecke, C.; Mehlhose, C.; Busch, G.; Spiller, A.; Brümmer, B. Der markt für milch und milcherzeugnisse im jahr 2019. Ger. J. Agric. Econ. 2020, 69, 67-92.

4. Hänsel, S.; Ustrnul, Z.; Łupikasza, E.; Skalak, P. Assessing seasonal drought variations and trends over central Europe. Adv. Water Resour. 2019, 127, 53-75. [CrossRef]

5. Demoustier, J.; Herzfeld, T. Aspekte der agrarpolitik 2018. Ger. J. Agric. Econ. 2019, 68, 1-17.

6. Swinbank, A.; Daugbjerg, C. The 2003 CAP reform: Accommodating WTO pressures. Comp. Eur. Politics 2006, 4, 47-64. [CrossRef]

7. Popp, T.R. Explaining policy convergence and divergence through policy paradigm shifts: A comparative analysis of agricultural risk governance in OECD countries. J. Comp. Policy Anal. Res. Pract. 2019, 58, 1-18. [CrossRef]

8. Pe'er, G.; Bonn, A.; Bruelheide, H.; Dieker, P.; Eisenhauer, N.; Feindt, P.H.; Hagedorn, G.; Hansjürgens, B.; Herzon, I.; Lomba, Â.; et al. Action needed for the EU common agricultural policy to address sustainability challenges. People Nat. 2020. [CrossRef]

9. Dionne, G. Handbook of Insurance, 2nd ed.; Springer: New York, NY, USA, 2013; ISBN 9781461401544.

10. Magnan, S. Catastrophe insurance system in France. Geneva Pap. Risk Insur. Issues Pract. 1995, 20, 474-480. [CrossRef]

11. Aase, K. An equilibrium model of catastrophe insurance futures and spreads. Geneva Pap. Risk Insur. Theory 1999, 24, 69-96. [CrossRef]

12. Eling, M.; Pankoke, D.A. Systemic risk in the insurance sector: A review and directions for future research. Risk Manag. Insur. Rev. 2016, 19, 249-284. [CrossRef]

13. Cummins, J.D.; Weiss, M.A. Systemic risk and the U.S. insurance sector. J. Risk Insur. 2014, 81, 489-528. [CrossRef]

14. Ozen, E.; Grima, S. Analysis of the influencing factors on the farmers' take-up of greenhouse agricultural insurance cover: A case study. Int. J. Econ. Bus. Adm. 2018, 6, 14-33. [CrossRef]

15. Pauly, M.V. The economics of moral hazard: Comment. Am. Econ. Rev. 1968, 58, 531-537.

16. Einav, L.; Finkelstein, A. Selection in insurance markets: Theory and empirics in pictures. J. Econ. Perspect. 2011, 25, 115-138. [CrossRef] [PubMed]

17. Daugbjerg, C.; Feindt, P.H. Post-exceptionalism in public policy: Transforming food and agricultural policy. J. Eur. Public Policy 2017, 24, 1565-1584. [CrossRef]

18. OECD. Agricultural Policy Monitoring and Evaluation 2019; OECD Publishing: Paris, France, 2019; ISBN 9789264332393.

19. European Court of Auditors. Farmers Income Stabilization: Comprehensive Set of Tools, but Questions of Low Uptake of Instruments and Overcompensation Need to Be Tackled; No. 23; European Court of Auditors: Luxembourg, 2019. [CrossRef] 
20. Komarek, A.M.; de Pinto, A.; Smith, V.H. A review of types of risks in agriculture: What we know and what we need to know. Agric. Syst. 2020, 178, 102738. [CrossRef]

21. European Commission. EU Budget: The Common Agricultural Policy beyond. 2020. Available online: https://ec.europa.eu/commission/presscorner/detail/en/MEMO_18_3974 (accessed on 29 July 2020).

22. Hartung, U. Extremwetterereignisse in der Landwirtschaft: Risikomanagement im Bundesländervergleich. Berichte Landwirtsch. Zeitschrift Agrarpolitik Landwirtschaft 2020, 98, 1-31. [CrossRef]

23. Grethe, H.; Arens-Azevedo, U.; Balmann, A.; Biesalski, H.K.; Birner, R.; Bokelmann, W.; Christen, O.; Gauly, M.; Knierim, U.; Latacz-Lohmann, U.; et al. For an EU common agricultural policy serving the public good after 2020: Fundamental questions and recommendations. Berichte Landwirtsch. Zeitschrift Agrarpolitik Landwirtschaft 2018, 1-96. [CrossRef]

24. Lipińska, I. Managing the risk in agriculture production: The role of government. Eur. Countrys 2016, 8, 86-97. [CrossRef]

25. Bardají, I.; Garrido, A.; Blanco, I.; Felis, A.; María Sumpsi, J.; García-Azcárate, T.; Enjolras, G.; Capitanio, F. Research for AGRI Committee. State of Play of Risk Management Tools Implemented by Member States during the Period 2014-2020: National and European Frameworks; European Parliament: Brussels, Belgium, 2016; ISBN 978-92-823-8632-3.

26. Walker, B.; Holling, C.S.; Carpenter, S.R.; Kinzig, A. Resilience, adaptability and transformability in Social-ecological systems. Ecol. Soc. 2004, 9, 5. [CrossRef]

27. Gallopín, G.C. Linkages between vulnerability, resilience, and adaptive capacity. Glob. Environ. Chang. 2006, 16, 293-303. [CrossRef]

28. Janker, J.; Mann, S.; Rist, S. What is sustainable agriculture? Critical analysis of the international political discourse. Sustainability 2018, 10, 4707. [CrossRef]

29. Urruty, N.; Tailliez-Lefebvre, D.; Huyghe, C. Stability, robustness, vulnerability and resilience of agricultural systems. A review. Agron. Sustain. Dev. 2016, 36, 2. [CrossRef]

30. Meuwissen, M.P.M.; Feindt, P.H.; Spiegel, A.; Termeer, C.J.A.M.; Mathijs, E.; Mey, Y.D.; Finger, R.; Balmann, A.; Wauters, E.; Urquhart, J.; et al. A framework to assess the resilience of farming systems. Agric. Syst. 2019, 176, 102656. [CrossRef]

31. Abson, D.J.; Fraser, E.D.G.; Benton, T.G. Landscape diversity and the resilience of agricultural returns: A portfolio analysis of land-use patterns and economic returns from lowland agriculture. Agric. Food Secur. 2013, 2, 1. [CrossRef]

32. Statistisches Bundesamt. Viehbestand. Fachserie 3 No. 4.1. 2020. Available online: https://www.destatis.de/DE/Themen/Branchen-Unternehmen/Landwirtschaft-Forstwirtschaft-Fischerei/ Tiere-Tierische-Erzeugung/Publikationen/Downloads-Tiere-und-tierische-Erzeugung/viehbestand2030410205314.pdf?_blob=publicationFile (accessed on 25 July 2020).

33. Yin, R.K. Case Study Research and Applications. Design and Methods, 6th ed.; SAGE: Los Angeles, CA, USA; London, UK; New Dehli, India; Singapore; Washington, DC, USA; Melbourne, Australian, 2018; ISBN 9781506336169.

34. Statistikamt Nord. Agrarstrukturerhebung. Available online: https:/www.statistik-nord.de/zahlen-fakten/ landwirtschaft/agrarstruktur/ (accessed on 25 May 2020).

35. Flyvbjerg, B. Five misunderstandings about case-study research. Qual. Inq. 2006, 12, 219-245. [CrossRef]

36. BMEL. Bericht des BMEL und der Länder Anlässlich der Amtschef- und Agrarministerkonferenz vom 26. bis 28. September 2018. Available online: https://www.bmel.de/SharedDocs/Downloads/Landwirtschaft/ AMK-18-09-Risiko-Krisenmanagement.pdf?_blob=publicationFile (accessed on 5 November 2019).

37. Vroege, W.; Dalhaus, T.; Finger, R. Index insurances for grasslands-A review for Europe and north-America. Agric. Syst. 2019, 168, 101-111. [CrossRef]

38. Kuehne, G. Eight issues to think about before interviewing farmers. Forum Qual. Soc. Res. 2016, 17. [CrossRef]

39. Lievens, E.; Mathijs, E. ResAT Assessment: Dairy Farming in FLANDERS. 2018. Available online: https: //www.biosfere.be/wp-content/uploads/2018/09/T.-4.2-Belgium-KUL-ResAT-assessment.pdf (accessed on 26 July 2020). 
40. Bezzina, F.H.; Grima, S. Exploring factors affecting the proper use of derivatives. Manag. Financ. 2012, 38, 414-435. [CrossRef]

41. Möllmann, J.; Michels, M.; Musshoff, O. German farmers' acceptance of subsidized insurance associated with reduced direct payments. Agric. Financ. Rev. 2019, 79, 408-424. [CrossRef]

42. De Vries, J.R.; van der Zee, E.; Beunen, R.; Kat, R.; Feindt, P.H. Trusting the people and the system. The interrelation between interpersonal and institutional trust in collective action for agri-environmental management. Sustainability 2019, 11, 7022. [CrossRef]

(C) 2020 by the authors. Licensee MDPI, Basel, Switzerland. This article is an open access article distributed under the terms and conditions of the Creative Commons Attribution (CC BY) license (http://creativecommons.org/licenses/by/4.0/). 